\title{
Phenomenology and Ethics: From Value Theory to an Ethics of Responsibility
}

\author{
Zeynep Direk \\ Koç University
}

\begin{abstract}
There seems to be a shift in phenomenology in the $20^{\text {th }}$ century from an ethics based on value theory to an ethics based on responsibility. This essay attempts to show the path marks of this transition. It begins with the historical development that led Husserl to address the question of ethical objectivity in terms of value theory, with a focus on Kant, Hegel, and Nietzsche. It then explains Husserl's phenomenology of ethics as grounded in value theory, and takes into account Heidegger's objections to it. Finally, it considers Sartre as a transitional figure between value theory and an ethics of responsibility and attempts to show in what sense, if at all, Levinas' phenomenology of ethics could be an absolute break with a phenomenological ethics based on values.
\end{abstract}

Keywords: Phenomenology, Ethics, Value, Responsibility, Husserl, Sartre, Levinas.

From a historical point of view, phenomenology's approach to ethics began with value theory. Although Max Scheler's and Nicolai Hartmann's works on ethics and value theory, namely, Scheler's Formalism $(1916)^{1}$ and Hartmann's Ethics (1926), ${ }^{2}$ were available and well-known, Husserl's work on these subjects only came to light after 1988, with Ullrich Melle's publication of his Lectures on Ethics and Value Theory. ${ }^{3}$ Since then, more phenomenologists have

${ }^{1}$ Scheler 1973 and Scheler 2000.

${ }^{2}$ Hartmann 1932 and Hartmann 1949.

${ }^{3}$ Hua XXVIII contains Husserl's lectures from 1908 to 1914, together with appendices and supplementary texts that reproduce manuscripts dating from 1897 to 1914 . Husserl's writings on ethics are also found in Hua XXXVII. 
realized that Husserl himself had a theory of value, one that inspired Scheler and Hartmann. The term value was employed in ethical discourses in nineteenth century philosophy, even though it did not play a major role in ethics before then. Until the end of the eighteenth century, the classical tradition of ethics made use of terms such as moral virtue, happiness, duty, utility, and moral sentiment in its preoccupation with the fundamental questions of ethics. Even though value played some minor role in their works, neither Kant nor Hegel had theories of value. Notwithstanding, the term played a major role in Nietzsche's and Marx's discourses on ethics. It came to determine the philosophical discourse of ethics at a time when a critical assessment of ethics was being made. Both Marx and Nietzsche were casting ethics into suspicion. Husserl responded to that suspicion of ethics, which he thought led to relativism, by claiming that ethics could have objective ground. He began his inquiry into values with an initial phenomenological question into the givenness of values. The originality of his ethics lies in the role assigned to affectivity in its account of normativity. According to Husserl, values are given in feelings. But how would values not be relative, if they are so given? In Lectures on Ethics and Value Theory, Husserl rejected the objection that value theory inevitably leads to relativism on the grounds that there are a priori elements of evaluation. ${ }^{4}$ However, whether recourse to formal axiological laws would allow him to save ethics from suspicion, refute moral skepticism, and avoid relativism has remained controversial. Even if ethical reasoning has formal a priori principles, this ethical objectivism does not seem capable of going beyond formalism, insofar as Husserl's theory of the material a priori remains unclear.

As Graham McAleer points out, "Value ethics, in fact, is the twentieth century's original contribution to ethical theory." Nevertheless, it receives so little attention in the continental tradition that it seems to have been forgotten or ignored. This forgetting or neglecting has a serious consequence: it makes it difficult to understand major transformations that have taken place in the history of ethics in the continental philosophical tradition. The continental style of instruction in ethics tends to compare classical philosophers-such as Aristotle, Aquinas, Hume, and Kant-with Levinas, and leave out value theories propounded by Husserl, Scheler, and Hartmann. For the analytic tradition's discussion of ethics, theory of value still plays a major function; whereas, for the continental (phenomenological) tradition, theory of value is largely ignored for addressing ethical questions.

Some scholars have explained this fading away of value theories by using Heidegger's objections to that tradition in Being and Time ${ }^{7}$ and "Letter on

\footnotetext{
${ }^{4}$ See Hua XXVIII: $137-42$.

${ }^{5}$ Nenon 1990.

${ }^{6}$ McAleer 2006: 218.

${ }^{7}$ Heidegger 1962.
} 
Humanism." ${ }^{8}$ Indeed, readers who are persuaded by his philosophy tend to find theories of value less attractive. Nevertheless, there are grounds to suspect whether this is the only reason that value theory has become so unfashionable. In order to understand the collapse of value-based ethical theories, regard for subsequent developments in the history of ethics over the course of the twentieth century is well-advised. In a recent essay on Levinas, Robert Bernasconi suggested that there has been a revolution in the twentieth century history of ethics. According to him, this revolution is to be found, less in the invention of the term responsibility as an ethical term, but more in responsibility's transcendence of its limits-extending itself toward hyperbolic and infinite responsibility - in the works of both Sartre and Levinas after the Second World War.' The significance of this transformation is better assessed by remembering that an ethics of responsibility has replaced value-based ethical theories; both Sartre and Levinas are certainly key figures in this transition from value theory to responsibility.

In Being and Nothingness, ${ }^{10}$ Sartre used both the terminology of value and of responsibility; he can, therefore, be seen as lying between the two paradigms of ethics, perhaps in the very transition from the first to the second. Levinas, on the other hand, can be read as having completely replaced a valuebased ethics with an ethics of responsibility. Even though Levinas had his own reasons for disagreeing with value-based ethics and its conception of ethical life, at crucial moments of his rethinking of ethics, he remained in dialogue with the phenomenology of values. In the first part, I speak briefly of the historical development that necessitated Husserl's attempt to reestablish ethical objectivity in terms of value theory at the beginning of the twentieth century. In the second part, I explain and outline problems for Husserl's theory of value, with a focus on Heidegger's objections to it. Finally, I assess whether these objections have played a role in the transition from a value-based ethics to an ethics of responsibility, such as appears in Sartre and Levinas.

\section{The invention of value as an ethical term}

I see three major moments in the development of the term value in the eighteenth and nineteenth centuries: first, Kant's distinction between relative (conditional) value and absolute (unconditional) value in Groundwork of the Metaphysics of Morals; ${ }^{11}$ second, Hegel's insistence, in Phenomenology of Spirit, ${ }^{12}$ on the intersubjective constitution of what is valuable in the world

\footnotetext{
${ }^{8}$ Heidegger 1977: 25.

${ }^{9}$ Bernasconi 2008.

${ }^{10}$ Sartre 1956 and Sartre 2000.

${ }^{11}$ Kant 2011.

${ }^{12}$ Hegel 1977.
} 
of objective spirit; and third, Nietzsche's critical remark, in On the Genealogy of Morals, ${ }^{13}$ that humanity fell prey to historically created values. By focusing on these three moments, it is possible to trace a movement from a conception of man as absolutely worthy as a rational being to a conception of man as unconsciously determined by values forged by history. My task here is not to comment on that movement from Groundwork of the Metaphysics of Morals to On the Genealogy of Morals. Rather, I stage this movement as the background for Husserl's rejection of Kantian formalism ${ }^{14}$ in grounding morality, and for his return to the Scottish school of moral sentiments.

These three moments may be specified as follows:

I. Value is originally a term from economics, in which goods, or things, have relative values, ${ }^{15}$ and enters ethics from a concern about the possibility of nonrelative (absolute) values. Kant argued that there is a rational ground for valuing persons, independently of who they are and what they achieve. In Groundwork for the Metaphysics of Morals, his second formulation of the categorical imperative commands that one always treat human beings - both self and others - as ends in themselves, and never merely as means for achieving particular goals. ${ }^{16}$ In commenting on this formulation of the categorical imperative, Kant distinguished between "price" and "dignity," noting that things with a price can be bartered, sold, or exchanged, whereas things with dignity (persons) cannot be treated in such economic ways. ${ }^{17}$ Hence, Kant held that human beings are without price: no matter what relative value one may have (in virtue of accomplishing, or assisting others to accomplish, goals), one also has absolute value as a person. He explicitly used the term Werth when he explained that persons are both subjective ends and objective ends: As subjective ends, they have worth for me by virtue of what they achieve or have the potential to do; however, as objective ends, their very existence is worthy of pursuit and preservation-independently of all subjective ends, absolutely-as rational beings. If there were no being whose existence was worthy or valuable independently of subjective goals, then "nothing whatsoever of absolute worth

${ }^{13}$ Nietzsche 1989.

${ }^{14}$ Hua XXVIII: 414-418.

15 "Value" as a term of economy determines a thing's place among things of the same kind and implies the price of something. Prices are determined within a market and, thus, in the movement by which human beings barter and exchange things or buy and sell things by means of money. Nevertheless, the value of something for someone may be more or less than its priced value: for example, a gift may be valued because it is given by a friend, and its value arises from the value placed on the friend. The same good or commodity may have no value for other people.

${ }^{16}$ Kant 2011: 428/85.

${ }^{17}$ Kant 2011: 434/97. 
could be found; but if all worth were conditional, and hence contingent, then for reason no supreme practical principle could be found at all." ${ }^{\prime 18}$

The absolute value of persons is grounded on the absolute value of a rational being, for which autonomy - the reception of the moral law from one's own reason, independently of desires and inclinations - is possible. In other words, the absolute value of persons is grounded on the absolute value of reason as the source of the moral law.

The requirement of the categorical imperative that the rule of an action could be universalized gives the principle for morally evaluating actions: an action has moral worth only if it is done from duty alone. However, it is impossible to know whether the moral law alone motivates the will, since it is always possible that actions in accordance with duty may also be motivated by a secret principle of self-love. Consequently, the categorical imperative provides a guideline without guaranteeing the moral worth of actions. In Formalism in Ethics, Scheler criticized Kant for making "the moral value of an action depend on its cost, on the sacrifices made by the one who acts." ${ }^{19}$ For an ethics of value, actions from duty and actions from inclination can coexist, and such coincidence confers an even higher value upon that action. Above all, value theory denies that duty's "ought" is the primordial ethical phenomenon; instead, it sees insights into values as fundamental and derives "ought" from "good." Kant denied the possibility of an intellectual intuition about value qualities within feeling. The determinability of the will by the moral law alone must be the source, not only of duties, but also of moral values. ${ }^{20}$ According to value theorists, such as Husserl and Scheler, Kant did not have a philosophy of value, even though he distinguished between moral values (of persons and actions) and relative values (of things), for his practical philosophy was based on a rejection of the possibility of a nonformal ethics of value. Husserl and his followers disagreed with Kant because they thought Kant's theory was too formal and not based on the experience of the world as a world of values. They did not reject formalism altogether, but rethought it, bringing formal elements together with nonformal, or material a priori, elements.

II. As Hegel argued, Kantian morality abstracts from the reality of the human world, and his universalism, which is based on an abstract notion of Reason, fails to account for the ethical substance-that is, the human world, which, in the language of phenomenology, can be called "a world of values." Hegel emphasized that the objectivity, the reality (Wirklichkeit), of this world is comprised of work and action. At stake in "Reason" (B) of Phenomenology of Spirit, is the actualization of self-consciousness through its own activity. ${ }^{21}$

\footnotetext{
${ }^{18}$ Kant 2011: 428/85.

${ }^{19}$ Scheler 1973: 228.

${ }^{20}$ Pippin 2000.

${ }^{21}$ Hegel 1977: \$347-393.
} 
Value theory also has a self-consciousness that actualizes itself in the world through its actions. In Phenomenology, "the law of the heart," "virtue," and "reason as lawgiver" are the shapes of consciousness upon which Hegel focused in order to account for that actualization. He did not address the consciousness of ethical values because, historically speaking, value theory had not been invented yet. The problem for which (B) provides a solution is also the problem for which value theory provides a solution: the constitution of the objectivity of the human world. Hence, speaking anachronously, if Hegel had been familiar with value theory, he probably would have included it in this part of Phenomenology, which challenges moral theories that presuppose a separation between the moral individual and the world, such as stoic virtue, Rousseau's law of the heart, and Kant's legislating reason. The problem with these theories lies in their inability to explain the genesis of an objective human world. In all these shapes, Hegel saw a tendency to address ethics in terms of laws; such laws appear as transcendent and abstract in the Kantian moral consciousness, which is a nest of contradictions. The most significant of these contradictions is the one between morality and nature, that is, between Reason and inclination (sense). The objective world cannot be the creation of the moral consciousness of the moral law-giver, which is indifferent to any empirical worldly content, because it is focused on the pure form of the moral law. How, then, do we account for it? Hegel answered this in "Reason" (C): "Individuality which takes itself to be real in and for itself." 22 In acting in such-and-such a manner, or in producing a particular kind of work, an individual may think that he intends the universal good, the good for everyone. But, if his fellow human beings do not get interested in what he does, and if they do not join him in this action or appropriate his work (in the sense of reworking and interpreting it), then what the individual has done or produced will have no objective or spiritual value. On the other hand, an individual may do something because of his or her own personal interest in it, and if "others hurry along like flies to freshly poured out milk," then that action or work acquires an objective or spiritual value. ${ }^{23}$ Here, Hegel provided an account of how spirit appears in the human world. Nothing will have value if it fails to become intersubjective. But this intersubjectivity does not issue from the universal legislation of my reason; rather, it is born of individual interests in the empirical world. Thus, he emphasized the irreducibility of the intersubjective element in the being of values, and made it the hallmark of objectivity. Here, value theory has a lesson to learn from Hegel. An understanding of objectivity or reality as Dingheit would be a source of confusion for value theories in the Husserlian tradition. Values do not have anything to do with the thing, in the sense of das Ding, rather, they are a matter of what becomes die Sache selbst.

\footnotetext{
${ }^{22}$ Hegel 1977: \$ 394-437.

${ }^{23}$ Hegel 1977: 418.
} 
Die Sache stands for the thing of value in the human world. Hegel defined it as that which "completely holds its own and is experienced as that which endures, independently of what is merely the contingent result of an individual action, the result of contingent circumstances, means, and reality." ${ }^{24} \mathrm{He}$ also noted that, in its immediate consciousness, die Sache selbst is "free, simple, and abstract" and "has the value of essential being." 25 This describes what is of worth, or valuable, in the world in general. Hence, "good" and "right" cannot be defined formally, independently of the content of work and action.

If they had been familiar with the language of value theory, both Hegel and Kant would have argued for the objectivity of values. But Kant would have been interested in the objectivity of moral value judgments, whereas Hegel would have been concerned with the objectivity of values in the historical human world. Obviously, both would reject any subjectivism that reduced values to subjective normative beliefs. Hegel opposed Kant, arguing that reason exists concretely in the human world, and values are part of its concrete existence.

III. Hegel can be read as giving expression to the ideas that the human world begins by sharing values and that the objectivity of values rests on intersubjectivity. He provided the philosophical ground upon which Nietzsche could regard values as historical creations. The Baden school of Neo-kantianism, and especially figures such as Wilhelm Windelband who seeks to go beyond Kant in order to understand him better can be a link in making the transition from Hegel and Nietzsche, besides Dilthey. Windelband rejects the correspondence theory of truth, describes truth as a value (which we confer to propositions which accord with the general standards of thought) and reflects on the epistemology of history. The historicism of Dilthey, which is different than Windelband's, rejects both the Hegelian philosophy of history, that is, the thesis that history has a dialectical logic and goal that transcend specific historical contexts and the Enlightenment claim that "there are universal moral standards that apply to all cultures and epochs." ${ }^{26}$ Thus, Hegel's rejection of individualism in ethics, Windelband's concern with truth as a value, and the historicist concern with political, moral, and religious values specific to historical periods shed light on Nietzsche's use of the term "value." Values make part of our facticity; they are there-in where we live-before we awaken to ourselves as self-conscious human beings. Nietzsche radicalized that position, claiming our relation to values remains historically unconscious. Getting rid of Hegelian idealism, while maintaining the insight that values are historically created through human interaction, Nietzsche reflected, in On the Genealogy

\footnotetext{
${ }^{24}$ Hegel 1977: 409.

${ }^{25}$ Hegel 1977: 411.

${ }^{26}$ Beiser 2011: 10 and 12.
} 
of Morals, on how this history could be interpreted, using a reversal of the significations of binary terms of value, such as "good and bad" and "good and evil." He compared the opposition between "good" and "bad," as found in the master morality of the ancients, with the signification of the opposition between "good" and "evil" in the slave morality of the moderns. ${ }^{27}$ Nietzsche proposed that slave morality results in the leveling-off of all differences, bringing about the death of man in nihilism. Furthermore, he raised the question of the possibility of creating new values that would enable human beings to affirm life.

In order to have distance from the values that operate in hypocritical ways in one's own society, one must make a distinction between values and value judgments. Hegel dismissed that distinction. For him, if we keep making value judgments about the world of values, then we are no more than beautiful souls that evade action. Can the evaluations we make, by appealing to social values, give us knowledge of the value of the action at stake? The generally accepted values of society may forbid lying and encourage telling the truth, but those norms may mislead in the evaluation of a particular action. It is possible to imagine some cases in which it would be morally questionable to make value judgments on the basis of such norms. This is the philosophical challenge that historicist approaches leave us with, and phenomenological value theory of the twentieth century can be seen as an attempt to meet it.

The phenomenological tradition attempts to make a new beginning, by transcending the historicity of values. In a sense, it seeks a way to appreciate the factical givenness of social values in the human world, understanding that our moral life is historically produced, but it also seeks a way to repeat the classical question concerning the possibility of rational action. Husserl started a new inquiry, after Kant and Hegel, on the force of motivation on the will that obliges it to choose a particular course of action, without making any assumption about transcendental freedom (our noumenal being), or about freedom as the unfolding of the Idea and the coming to self-consciousness of Spirit. Further, he kept silent about the absolute value of persons because the recognition of persons, as ends in themselves, does not solve the problem of determining the best action in given concrete circumstances. According to Nietzsche, values do not have transcendent origins: they are part of the world of immanence-the social, cultural, and linguistic world. Husserl agreed with Nietzsche on this point. Nevertheless, he believed, at the same time, that values in the world are objective, that is, recognizable in principle as major motives in the choice of action. Moreover, he argued that evaluations might be correct - if they accord with formal, as well as material, a priori structural relations.

${ }^{27}$ For Nietzsche, slave morality began with Christianity. However, it became stronger, as a universal secular position, in modernity. 


\section{Husserl's value theory and Heidegger's objections}

Value theory is Husserl's response to a more general question that includes ethics. It makes it possible to account for the human world, which cannot be reduced to a collection of objects, and to whose domain ethical problems properly belong. Between the winter semester of 1908/09 and the end of the summer semester of 1914, Husserl held three lecture courses on ethics and value theory. These lectures are published in the volume of Husserliana XVIII, "Lectures on Ethics and Value Theory." For Husserl, there are doxic (cognitive), affective (emotional), and conative (volitional) mental phenomena, and theoretical, normative, and practical disciplines could be seen as developing through the study of the intentional matter of these three kinds of acts. His theory of affects is at the same time a theory of valuations because he held that affects are implicitly valuations. As John Welsh Jordan puts it, "Husserl needed a normative subdiscipline in his theory of affects (axiology), in order to distinguish between correct and incorrect emotions." 28

The influence of Franz Brentano's work on morality on Husserl's lectures cannot be underestimated: The Origin of Our Knowledge of Right and Wrong, written under the influence of Austrian economists, is the foundation of the value theory in the phenomenological tradition. Brentano wondered about the origin of knowledge of right and wrong, and engaged in a new reflection on founding law on morality. Husserl took over from Brentano his idea of axiology as well as his early categorical imperative. While Husserl seemed to correct and extend his teacher's work, he departed from it in fundamental ways. Certainly, there are several differences between Brentano's and Husserl's value theories. Here, I shall only point to two broad lines of difference. The first, as John Welsh Jordan argued, the mark of Husserl's distinction from Brentano is the distinction between axiology and ethics. ${ }^{29}$ Unlike axiology, ethics concerns more than the correctness of evaluations: it must account for both volition and the correctness of representations. Hence, ethics is a practical discipline that relates to both theoretical and normative disciplines. Secondly, Husserl's and Brentano's classifications of mental phenomena are different. Brentano distinguished between cognitive and affective mental phenomena; volitions, seen as feelings, made part of the latter. ${ }^{30}$ In contrast, Husserl organized mental

${ }^{28}$ Jordan 1997.

${ }^{29}$ Jordan 1997.

${ }^{30}$ Brentano distinguishes between ideas, judgments and emotions. Ideas and judgments fall within the group of cognitive phenomena. Ideas cannot be true or false, only judgments are true or false; in contrast, emotions can be correct and incorrect. We prefer true judgments to false judgments but preference works differently in matters concerning the good: "Is this true or false?" In this case, there is certainly a kind of preference. But it is always a matter of preferring something true to something false; it is never a matter of preferring something "more true" to something "less true". Everything that is true is equally true; but not everything that is good 
phenomena according to a threefold distinction: doxic (cognitive mental phenomena), affective (emotional mental phenomena), and conative (volitional mental phenomena).

Husserl started with the fundamental convictions that persons live in a world of values, and, as rational agents, individuals must create hierarchies of value in order to live good lives and act in morally right ways. Presuming free choice, the answers to ethical questions could properly be given in terms of values. If so, an explanation of human deeds, choices, and endeavors requires an account of how they are motivated by valuations. Values are revealed by emotions; having been motivated by some values rather than others, the will chooses actions that promote or realize those values in the world. Husserl believed that actions are chosen by acts of volition, and these acts must be motivated by the presentation of something as valuable. According to this view, one desires things that are evaluated positively. The positive evaluation of something is a necessary condition for its being the object of volition; and, given that condition, that evaluation is the foundation (Fundierung) for every act of will.

In Lectures on Ethics and Value Theory, Husserl interpreted the history of ethics as an ongoing debate between the sentimentalism of the empiricist tradition and the intellectualism of the rationalist tradition. Husserl denied the rationalist metaphysical grounding for unconditioned objectivity and validity of ethical norms in God, nature, and the formalities of pure reason. He felt closer to the tradition of British moralists, and took Hume's notion of moral sentiment seriously. Hume held that, if we abstract from feelings, then the world—as merely perceived—consists of bare objects, events, and processes. However, one does not live in such a world; the world of matters of fact only becomes a human world through positive and negative responses. Looking back, from value theories of the twentieth century, to Hume's moral philosophy, Hume appears to be the first thinker to take passions as valuations. Love and the feeling of approval signal the positive reception of something in experience; hatred and the feeling of disapproval imply the rejection or refusal of something. Hume stressed, further, that the feelings of approval and disapproval arise only when one adopts an "objective point of view" - that is, when one ignores one's own proximity to the object of evaluation. According to Hume, the objective viewpoint saves morality from being completely subjective and relative. Hume thought that although it is a logical fallacy to derive "ought" from "is," this is how "ought" proceeds from "is," and thus rejected the need for another account of moral normativity. Hume's account of moral evaluation is not grounded on a metaphysical account of values: even

is equally good. When we call one good "better" than another, we mean that the one good is preferable to the other. In other words, it is correct to prefer the one good, for its own sake, to the other" (Brentano 2009: 16). 
though the fundamental problem of value ethics already appeared in $A$ Treatise of Human Nature (II and III), Hume did not use the term value in the same (technical) sense used by the value theory tradition in the twentieth century. ${ }^{31}$ Indeed, the term appears very rarely in Hume's moral writings.

According to Husserl, the reception and the rejection Hume talked about create the value properties of things that make the world a human world. From Hume, he adopted the idea that objects as having value properties are given to us in feelings. Nevertheless, he hoped to escape the skeptical consequences of an ethics based on sentiment-that is, ethical relativism and hedonism-by conceding to the rationalist tradition the existence of objectively valid ethical norms and rules-namely, material and formal a prioris. Material and formal a prioris were introduced in a polemic with Kant, which Scheler made more explicit in Formalism in Ethics. ${ }^{32}$ Kant sought to identify "good" with "duty." He was correct to reject the notion that good and evil are value things that are contents of the will. But he was wrong to refuse to see good and evil as non-formal values. What Husserl objected to in Kant's practical philosophy was not the latter's emphasis on universal and absolute obligations, but his insistence that the source of the unconditioned validity of ethical norms cannot be anything other than the categorical imperative. As Henning Peucker noted, "From a phenomenological point of view, therefore, the idea of a purely formally determined will makes no sense. Husserl consequently maintains that Kant's concept of a purely formally determined will is in the last analysis widersinnig, that is, 'counter-sensical." 33 Kant would have absolutely rejected that concepts include a value content constituted by affective consciousness (Gemütsbewusstsein). Husserl accused Kant of formalism and called into question his exclusion of any material content from the foundations of ethics. The role Husserl made emotions or feelings play in morality marks his distance from Kant's philosophy. For Kant, feelings were part of our sensible mechanical nature and the will could not be free if it was determined by desires, feelings, and inclinations. Sensibility was strictly excluded from Kant's grounding of morality on a metaphysic of morals. Husserl rejected an ethics founded on the radical separation between the faculties of sensibility and reason; he thereby opened himself to rethinking the relation between emotion and reason as an intentional relation. Feeling is a specific intentionality, for which there is an original correlation between acts of feeling and valuable beings. By means of intentionality, Husserl negated the characterization of sensibility as subject to causal mechanical determination. In the a priori correlations that emotions carry in themselves, formal and eidetic laws can be uncovered. This is ultimately the reason Husserl thought his theory escaped

\footnotetext{
${ }^{31}$ Hume 1982.

${ }^{32}$ Scheler 1973: 27.

${ }^{33}$ Peucker 2007: 317.
} 
skepticism and relativism. However, as Tom Nenon pointed out, Husserl's own account also remained quite formalistic, as he did not sufficiently explain the material a prioris of correct evaluation. ${ }^{34}$

The difficulties of value theory are inseparable from the difficulties in comprehending intentionality. Indeed, the world appears as valuable because intentional consciousness values things, events, people, deeds, situations, and so forth, but this does not entail that values are subjective products: intentionality is a structure in which the relation precedes and makes possible the relata-the subjective and the objective poles. The valuing subject and the valued object (that is, the world of values) coappear, thanks to the movement of intentionality. Their coappearance is the sole ground for the possibility that, even though values are only present to a valuing consciousness, the being of values transcends each psychological being. Therefore, values belong to the human psychological constitution as much as they belong to the world, but neither dimension - mind or world - is the true site for phenomenological research into values: values belong to transcendence in immanence, which can only be explored in these a priori correlations.

Yet, the problem of how something appears as an object of value to consciousness is a problem of constitution that phenomenologists have had difficulty solving. Acts of evaluation are value-feeling acts (wertfühlender Akt) and, as such, they have a different status than theoretical acts. As Levinas pointed out in Theory of Intuition, while value-feeling is not representation or objectivation, value-feeling acts presuppose objectifying acts. ${ }^{35}$ What is the connection between the intentional theoretical acts that constitute an object as an object, that represent it as such, and the value-feeling acts that relate to value-predicates in the object? Husserl's formulation for the givenness of objects with value-properties in feelings is not at all clear. Husserl rejected the assumption that judgments - acts of predication - provide one's primary relation to values. Using the term Wertnehmung, he indicated that the most elementary level of value experience is lived, not in the mode of judging consciousness, but in the mode of feeling consciousness. The term Wertnehmung (taking as valuable) echoes Wahrnehmung (perception). Perception is the act by which something is taken as true, or really there. Just as perception is a mode of pre-predicative experience, taking something as valuable in feeling is a pre-predicative experience. At the pre-predicative level, things not only appear in their sensuous apparition; they also show themselves as carrying value-properties. It is in pre-predicative experience that one reacts to objects positively or negatively_liking or disliking, and being pleased or displeased by them. Thus, the ego is not simply affected by the objects of nature; it is also affected by objects that carry value properties, which means that feelings

\footnotetext{
${ }^{34}$ Nenon 1990.

${ }^{35}$ Levinas 1995; Levinas 1963.
} 
involve a passive synthesis by which an object first appears valuable. Thus, Husserl thought feelings were capable of revealing value. Value judgments depend upon, or presuppose, these emotional attitudes or feelings. They make explicit what is already experienced in feeling.

The classical problem in this approach can be seen more explicitly in Hume, the thinker who first gave a constitutive role to feelings in accounting for the human world. The realm of nature is the realm of matters of fact, and it is apprehended through the psychological habit of thinking events as causally related. If the realm of nature is devoid of values, then a human world of values does not exist at all without the faculty of feeling. The faculties of perception and thinking enable the human mind to relate to nature; however, the mind's relation to values is via the faculties of desire and will. For example, flowers are both natural objects (plants) and they are valuable for me. How is it possible to both perceive and value the same thing, for nature and the value world to overlap? Insofar as there are not two separate entities, but only one, what accounts for the interlacing of fact and value, of ideas and value? Husserl faced the same problem because the experience of something as a valuable object implies, both its apprehension as an object, and a valuing act. The difficulty is to account for this extremely complex constitution. For some commentators, everything is quite clear: Husserl presupposed the priority of the objectivity of the object; for him, the givenness of the object in perception precedes its givenness as valuable. If this is the case, then the world of nature (as bare facts) precedes the human world (of significations). Others argue that the relation between the objective properties of objects (Eigenschaften) and their value-predicates (Wertschaften) remained unclear in Husserl's account. Are they different properties, or the same properties? Insofar as value-predicates are founded on material-predicates (Sachprädikaten), they supervene on the properties of objects. One both perceives properties of objects and is emotionally affected by their values. Although the perceived property is constituted out of hyletic data and the value property out of feeling data (Gefühlsdaten), Husserl did not satisfactorily explain how these data are interrelated. ${ }^{36}$ This is the point at which Heidegger's doubt about Husserl's value theory makes sense: his main question concerned whether feelings_-as the givenness of eidetic structures - must be subordinated to an analysis in terms of the opposition between subject and object.

There have been two fundamental blows to the tradition of value theory in the twentieth century. The first came from the logical positivists and Wittgenstein, who claimed that the propositions of ethics have no meaning, and the second came from Heidegger. Here, I focus on the second objection. In "Letter on Humanism," Heidegger called a philosophy of values "the greatest

${ }^{36}$ See Peucker 2007: 319. 
blasphemy imaginable against Being." ${ }^{37}$ The explicit target of that remark was Sartre, who, in Being and Nothingness, spoke of the irreducibility of consciousness's relation to values. Sartre adopted the term value from phenomenology's value theory tradition, specifically from Max Scheler's Formalism in Ethics. Scheler criticized and corrected Husserl's philosophy of value by providing the element of the material a prioris that Husserl had failed to clarify.

So far as I know, Sartre had no awareness of Husserl's work on value theory. Already in 1934, Sartre was familiar with the grounding of value theory on intentionality, ${ }^{38}$ and he argued that the value of an object (of love) does not depend on the value I give it by an evaluative act, but rests in the properties of the object itself. This assertion conformed to his understanding of intentionality: Consciousness is transcendence, a relation with alterities that are there in the world. Intentionality also gives access to what presents itself as valuable. Sartre referred to Scheler, both in Being and Nothingness, and in Notebooks for an Ethics. In Being and Nothingness, he addressed the question of the being of values, and argued that value is beyond being, showing that value enters the world through human reality and can be conceived as "that towards which a being transcends its being." ${ }^{39}$ From this account of the ideality of values, he described consciousness's relation to values in terms of the structure "manquant-manqué" (lacking, lacked)." He therewith claimed that "value haunts freedom," and "value haunts the for-itself." ${ }^{40}$ In Notebooks, he introduced his own hierarchy of values, which opposed Scheler's Christian version. ${ }^{41}$ Sartre rethought Scheler's fundamental concept of personality-understood in terms of relation to values - and complicated it with his notion of "being for itself." Even though he was concerned with describing the complex structures of a subject's relation to values, he also claimed that the objectivity of values is grounded on free choice. While this position may, at first sight, seem paradoxical, Sartre substantiated it in "Existentialism and Humanism." 42 Even though consciousness experiences values as already there in the world, the being of values is such that they only really exist for consciousness insofar as they are assumed by it. In a sense, free choice makes values exist. Sartre's account of the universal validity of ethical values was based on a conscious attitude: When I choose to act by a value, I also propose it to all humanity. Whether this approach succeeds in overcoming relativism is controversial, but Sartre thought it did overcome the subjectivism of value choice: the being of value is intersubjective-in principle-because it is impossible to have a value without also willing that others share it.

\footnotetext{
${ }^{37}$ Heidegger 1977: 251.

${ }^{38}$ Sartre 1947.

${ }^{39}$ Sartre 1956: 93 (translation modified).

${ }^{40}$ Sartre 1956: 94.

${ }^{41}$ Sartre 1992: 275 and 470; Sartre 1983: 486 and 576.

${ }^{42}$ Sartre 1973.
} 
Sartre tied the philosophical problem of values to the problem of the self. In Being and Nothingness, consciousness becomes a self through its relation to the values it adopts as ideals and, thereby gives existence. Moreover, this relation to values allowed Sartre to explain why consciousness never coincides with the facticity of human reality. Indeed, Sartre's philosophical position about values contributed to his characterization of consciousness as transcendence. He characterized the self as suffering from a lack; values are present in consciousness as demands for what is lacking in the self. Actions can never satisfy the demands made upon the self by values because no action can adequately satisfy or realize value; it can, at best, approximate it.

While Heidegger specifically targeted Sartre's philosophy in "Letter on Humanism," he aimed to devastate the broader tradition of philosophy of values that began with Husserl and culminated in Scheler and Sartre. From a historical perspective, his attack on the tradition of value theory has been extremely influential: his remarks were sufficient to stop those who took Heidegger seriously from taking "value" as the key concept of phenomenological ethics. More importantly, whether phenomenology should have an ethics at all became a question. Heidegger's discourse not only presented value theory as a pseudo-domain of research, which could only exist within the metaphysical tradition of the forgetting of Being, he was also critical of treating ethics as a separate discipline. In other words, the division of philosophy into separate disciplines followed from the oblivion of Being. What is so hard to remember is the original experience of all beings as gathered in logos, an original saying whereby the truth of Being comes into language. This experience is original, in the sense that it mediates all relations with beings in epochs of the truth of Being. In "Letter on Humanism," Heidegger explained how the fundamental ontology he offered in Being and Time prepared the ground for an understanding of the history of Being. Accordingly, the most important contribution that Being and Time made to his overall project is that it recast the essence of human being in terms of its relationship to Being. Heidegger claimed that thinking of Dasein's being as ecstatic existing and seeing its unity as care lead to an original attitude, for which ethics, as a special discipline, is unnecessary. Care is not a moral term or principle; it is ontological. As such, all thinking about practical matters must refer to it. Dasein, in caring for its own being, cares for beings as a whole. On this ground, Heidegger claimed that Dasein is the shepherd of Being.

In Letter on Humanism Heidegger implies that Husserlian value theory cannot escape subjectivism because it is based on the opposition between subject and object. And, insofar as it takes this opposition to be fundamental, it contributes to the forgetting of Being. But in Being and Time his critique of value theory is not so much about moral values; it aims at showing that value theory constitutes "things of use" by way of investing "things of nature" with value characteristics ["wertlichen" Beschaffenheiten]. Heidegger shows that 
this refers back to the Cartesian understanding of nature as res extensa. ${ }^{43}$ The "investment of value" remains ontologically obscure ${ }^{44}$; for value is added as if "bonus over and above what is already present-at-hand." ${ }^{45}$ As a consequence, "the phenomenological characteristics of Being which belongs to what we encounter in our concernful dealings" ${ }^{46}$ is missed. To take the human world as consisting of things invested with value hides the worldhood of the world from sight. ${ }^{47}$ Indeed, the whole question of the worldhood of the world in Being and Time was a rejection of the use of value theory to account for the being of the world.

Heidegger is well aware that the term value serves two purposes in phenomenology, accounting both for the constitution of the human world (the world in which human beings live their lives) and for the possibility of ethics. Indeed, these two ends (for which value theory is used) were not separate in Husserl's work; Scheler and Hartmann made that distinction later. For the phenomenologist, a tool is an object with value conferred upon by the relation a human being has to it. The world signifies for me because I relate to objects for practical purposes. Heidegger argues in Being and Time that this way of thinking is problematic because it presupposes the underlying validity of the understanding of Being as present-at-hand. Moreover, the phenomenological understanding of the world remains within the subjectivist horizon of modern philosophy in so far as it understands values as special properties of objects that subjects attach to things. Phenomenology attempted to solve the problems of ethics in the same way, asserting that a thing is good because consciousness feels that it is so, evaluating it as such. And, Husserl strove to show that consciousness so evaluates the object because the object has the property that makes it good.

Husserl's ethics postulated a subject capable of choosing the best course of action by reevaluating the world in which values are encountered. Husserl's version of the categorical imperative commands to do what is best in a given situation. According to the formal rule of absorption, the better absorbs the good and the best absorbs the better. Each is free to choose actions, and the good life is achieved by performing actions that are based on the correct evaluation of what is best in the situation. Making the correct evaluation is a function of formal and material a prioris, that is, the functioning of axiological laws and the intuitive knowledge of what different values are and how they relate to one another. Intuiting the essence of a value in feeling acquaints one with a material a priori. Here, the possibilities of self-deception and of deception about values are precluded. Heidegger did not think subjectivism could

\footnotetext{
${ }^{43}$ Heidegger 1962: 418.

${ }^{44}$ Heidegger 1962: 69.

${ }^{45}$ Heidegger 1962: 80.

${ }^{46}$ Heidegger 1962: 69.

${ }^{47}$ Heidegger 1962: 150.
} 
be overcome by taking into account the eidetic laws that make something what it is. According to him, Husserl started with the opposition between subject and object and aimed at proving the objectivity of values, but he did not realize that his project was nonsense because, if the value of something rests on our evaluation, valuing it would at the same time be devaluing it. "Every valuing, even where it values positively, is a subjectivizing. It does not let beings: be. Rather, valuing lets beings: be valid — solely as the objects of its doings." ${ }^{48}$ Heidegger preferred to drop the term value altogether, since it is grounded on the notion of an evaluating subject: Dasein's essence must be re-thought, starting from Dasein's ecstatic existence as an openness by which Being claims thinking. Can there be a new thinking of values on the basis of "care"? Heidegger made clear that "care" does not license a philosophy of value at all; on the contrary, it serves to close the domain of ethics by asserting the primacy of ontology over it. In Heidegger, Dasein's responsibility is for its there, primarily for the existential relation it has with Being. Thus, "Man is not the lord of beings. Man is the shepherd of Being", ${ }^{49}$ which is a way of saying that Dasein is responsible for the manifestation of all beings, for the essence of manifestation as such.

\section{From value theory to responsibility}

When Levinas raised the question of the meaning of ethics after Husserl and Heidegger, and radicalized the notion of responsibility by making it infinite, he responded, both to Heidegger's refusal to locate responsibility primarily in interhuman relationships, and to value theories belonging to the phenomenological tradition. Very little work has been done on Levinas's relation to value theory..$^{50}$ His objections are scattered across several texts, from Theory of Intuition onwards. Nevertheless, it would be wrong to represent Levinas as out of touch with value theory. Both in Totality and Infinity and in Otherwise than Being, he sought a different relation between phenomenology and ethics, using what he thought worth reconsideration in old-style phenomenology of values. The distance he took to value theory is also accounted for in "The Contemporary Criticism of the Idea of Value and the Prospects of Humanism," a text published in 1979. ${ }^{51}$

What is wrong with value theory from the point of view of an ethics of responsibility? As McAleer says, "The value theorist looks at the world with its highs and lows but still sees a spread of values and of individual persons

\footnotetext{
${ }^{48}$ Heidegger 1977: 251.

${ }^{49}$ Heidegger 1977: 245.

${ }^{50}$ For an exception, see Careau 2002.

${ }^{51}$ Levinas 1979.
} 
struggling to attain value." ${ }^{52}$ Because persons are bearers of different-higher and lower-values, they do not have equal worth. The subject's knowledge of values precedes and governs all justice and responsibility in relation to others. McAleer suggested that the perfectionism implicit in value theory is an indication of its conservatism. Value theory, especially as it culminates in Scheler's Christian hierarchy of values, has been an inexhaustible resource for conservative ethics. It may also be worth asking whether the downfall of value-based ethics after the Second World War may be a result of using the language of values for fascist political ends. Ultimately, moral purification of society was an end to be achieved by the elevation of one particular race over all others.

In value ethics, one aims to concretize already familiar values. Moral actions are triggered by value feeling, and freely chosen by the will. They aim at realizing, in the world, a value given to consciousness in feeling. If motivated by a positive value, action will be morally good and help to make the world a better place. Value theories limit responsibility to freely chosen personal actions, which are the subject's own doing. Ethics of responsibility, as it appears in its radical form in Levinas's philosophy, rejects several premises of value ethics. The I is not affected by something ideal and abstract, such as a value, but by the expression of the face of the Other, who commands me. This ethics of responsibility does not begin with an inquiry into the value(s) of persons and things, but posits—as original — the Other's questioning of my being. Questioning freedom includes questioning the hierarchy of values through which I experience or constitute my lived world. Levinas replaced the will-motivated by values - with an infinite desire for the Other. In the face-to-face relation with the Other, I am not free: my responsibility is not grounded on my freedom. Hence, I am responsible, not only for my situation, but also for deeds that are not my own. Moreover, responsibility is infinite, in the sense that it can never be fulfilled. I can never say that I have done what I could; rather, my responsibility increases with each response to the demands of the Other.

I track Levinas's use of the term axiology here, in order to relate his notion of responsibility to Husserlian value theory, despite all divergences that appear at the first sight. In Theory of Intuition, Levinas pointed to the problem of phenomenology's ontological concern with the representation of objects, even as it opened a new area of axiological research. Although axiology was a completely new area of phenomenological research, ontology seemed to precede it. How committed was Levinas to this new domain of phenomenological research? The term value played a crucial role at different points in Totality and Infinity. For example, Levinas appealed to "value" when he explained "enjoyment." He rejected the idea that life as pure being (bare life) could be called "life:" "Life is an existence that does not precede its essence. Its essence makes

${ }^{52}$ McAleer 2006: 219. 
up its worth [prix]; and here value [valeur] constitutes being." ${ }^{33}$ Enjoyment, the seeking of happiness, belongs to the essence of life. The value of life does not supervene on the being of life; on the contrary, it constitutes its being. And, in that sense, there is as much room for speaking of "quality without substance" as of "value without objective property." A theory of value-better, an axiology - was implicit to Levinas's account of the separation of the I. He said, "The upsurge of the self beginning in enjoyment, where the substantiality of the I is apperceived not as the subject of the verb to be, but as implicated in happiness (not belonging to ontology, but to axiology) is the exaltation of the existent as such". ${ }^{54}$ Sensibility, in its function for enjoyment, would be an object of an axiological, rather than an ontological, analysis. Even though there is no ethics at this level, ethics presupposes this axiology, which is incommensurable with ontology. Certainly, this point bears upon an explication of the intriguing statement, "ethics precedes ontology." Nevertheless, Levinas's rethinking of axiology rose to a new level when he related it to the encounter with radical alterity in the face-to-face relation with the Other. Without any doubt, the event of the face-to-face encounter played a key role in Levinas's own phenomenology because, besides other reasons, it was the starting point for Levinas's original response to phenomenology's fundamental question: How does the (human) world, as a totality of significations, appear as meaningful? Levinas argued that both the world of objects and the human world (the world of values) first originate from the expression, the signification, of the Other's face. Values come from the Other; in other words, the Other reevaluates all values. Value theory is transcended by an ethics of responsibility at precisely the point at which the world becomes a value world (a human world), thanks to the self-expression of the Other's face. Value theory has always been concerned with my own experience and choice; nevertheless, it did not see that values originate in a relation of discourse with the Other. Responsibility for the Other, which is infinite, precedes my responsibility for my own values.

As I have shown, value theory's classical problem has been the possibility of a relation between the value properties and the objective properties of things. Levinas shaped this problem differently, by adding another structural component to it: the relation to radical alterity. Indeed, in Cartesian Meditations, Husserl had already pointed to the structural dependence between the question of the alter ego and the possibility of both objective knowledge and the formation of a world of values. ${ }^{55}$ According to him, this did not contradict

53 Levinas 1992: 112.

54 "Le surgissement de soi à partir de la jouissance et où la substantialité du moi est aperçue non pas comme un sujet du verbe être, mais comme impliqué dans le bonheur ne relevant pas de l'ontologie, mais de l'axiologie_est l'exaltation de l'étant tout court," Levinas 1984: 91-2 and Levinas 1992: 119.

${ }^{55}$ Husserl 1982. 
with the grounding of his value theory on subjectivity rather than the relation with the Other. In Totality and Infinity, Levinas objected to that orientation. He believed that the value world could not be accounted for in terms of the world of objects because it springs from the relation with the Other. My relation with the Other is not governed by values, but by responsibility. That is to say, both responsibility and the value world it gives rise to precede ontology.

In Otherwise than Being, Levinas followed value theory's fundamental strategy of relating ethics to affectivity. His rethinking of sensibility transformed value theory, which is handicapped by the question of the relation between value properties and objective properties, into a theory of responsibility as substitution for the other. Instead of starting with a subject that is already correlated to a system of values (Husserl), or haunted by ideal values (Sartre), Levinas began with the I in the accusative mode: a hauntological subject, accused of crimes beyond personal deeds. Incessantly thrown back onto itself, the identity of the I is constituted by its being thrown back onto itself in recurrence. Furthermore, Levinas described transcendence in terms of obsession: the I is taken out of itself by obsession, and obsession directed towards substitution for the other. Responsibility is not based upon previous commitment or present attachment to a hierarchy of values, but stems from the anarchy of a diachronic proximity to the neighbor. Although this description amounts to a more radical rejection of the fundamental tenets of value ethics, Otherwise than Being actually follows a direction that was already present in Levinas's reception of value theory. There, Levinas took up the questions of sensibility and affectivity, in order to show what it would mean to think of sensibility as substitution beyond the relation to objectivity and axiology. In Totality and Infinity, an axiology beyond ontology was described; in Otherwise than Being, this axiology was deemed to remain intéressement, that is in essence, or care for the self. Thus, even though it is otherwise than being, it is not beyond essence. Responsibility, on the other hand, requires both. Levinas's attempted to show that responsibility—as substitution —is signification beyond essence. ${ }^{56}$

In "The Contemporary Criticism of the Idea of Value and the Prospects for Humanism," Levinas's paper for a conference on value theory, he explains his position as follows: Antihumanists think through the insight that the human being is inferior, with which he agrees. According to Levinas, antihumanism considers man, not as interiority, but as an individual of a genus or as a being in an ontological region. In other words, it gives precedence to the impersonal neutral that shapes man. There is no privilege in man that would make him the telos of reality. Levinas disagrees that this inferiority derives either from metaphysics or from the end of metaphysics. ${ }^{57}$ Rather, it results from the

\footnotetext{
${ }^{56}$ Levinas 1997: 99. Cf. and Levinas 1990: 156.

${ }^{57}$ Levinas 1979: 185.
} 
impossibility of self-adequation. The distance between the I and the Self being irreducible, the recurrence of the I to the Self is impossible. Indeed, value experience is made in this inferiority of the self that could not close itself on itself ${ }^{58}$, that could not sever the relation to the Other. "The recurrence of the I to the Self is impossible. It is impossible, for no one can remain in himself, for the humanity of man is a responsibility for all." 59 Thus Levinas finds the possibility of transcendence that antihumanism denied to the human, in this inferiority interpreted as recurrence. It is still possible to have value and to privilege man; if value stems from the Other. He says: "I ask if in this way the Other Person is not a value. Modem anti-humanism is perhaps not right in not finding in man, lost in history and the order of things the trace of this responsibility which makes a subjectivity and, in the other person, the trace of this value." ${ }^{60}$ Thus the prospect for a new humanism begins with the human inferiority but overcomes antihumanism by recognizing in the Other the trace of values, and in man the trace of infinite responsibility.

I have tried to show how Levinas's ethics of responsibility stood in relation to value theory in order to account for the transition from an ethics based on value theories to an ethics of infinite responsibility. Let me stress the fundamental difference between these approaches: When responsibility is grounded on values, freedom of choice lies at the foundation of ethics, and choice is based on affective life. Hence, the subject's recognition of values precedes its responsible relation with the Other. An ethics based on responsibility rejects that structure: Responsibility for the Other precedes both ontology and axiology.

\section{Zeynep Direk}

Koç University College of Social Science and Humanities, Department of Philosophy Social Sciences Building, Room 133

Rumelifeneri Yolu, 34450 Sariyer - İstanbul Turkey zdirek@ku.edu.tr

\section{Works Cited}

Hua XXVIII = Husserl, Edmund. 1988. Vorlesungen über Ethik und Wertlehre, 19081914, ed. Ullrich Melle. The Hague: Kluwer Academic Publishers.

Hua XXXVII = Husserl, Edmund. 2004. Einletung in die Ethik, Vorlesungen Sommersemester 1920 und 1924, ed. Henning Peuker. Dordrecht: Kluwer Academic Publishers.

\footnotetext{
${ }^{58}$ Levinas 1979: 183.

${ }^{59}$ Levinas 1979: 185.

${ }^{60}$ Levinas 1979: 187.
} 
Beiser, Frederick C. 2011. The German Historicist Tradition. Oxford: Oxford University Press.

Bernasconi, Robert. 2008. Before Whom and for What? Accountability and the Invention of Ministerial, Hyperbolic, and Infinite Responsibility. In Diffculties in Ethical Life, ed. Shannon Sullivan, Dennis J. Schmidt, 131-146. New York: Fordham University Press.

Brentano, Franz. 2009. The Origin of Our Knowledge of Right and Wrong. Trans. Roderick M. Chisholm, Elizabeth H. Schneewind. New York: Routledge.

Careau, Francis. 2002. La question des valeurs dans Totalité et Infini de Lévinas. Horizons Philosophiques 12 (2): 33-44.

Hartmann, Nicolai. 1949. Ethik, Dritte Auflage. Berlin: Walter de Gruyter \& Co.

Hartmann, Nicolai. 1932. Ethics. Trans. Stanton Coit. London: George Allen \& Unwin Ltd.

Hegel, G.W.F. 1977. Phenomenology of Spirit. Trans. A.V. Miller. Oxford: Oxford University Press.

Heidegger, Martin. 1962. Being and Time. Trans. John Macquarrie, Edward Robinson. New York: Harper and Row Publishers.

Heidegger, Martin. 1977. Letter on Humanism. In Basic Writings, ed. David Farrell Krell, 217-265. New York: Harper \& Row.

Hume, David. 1982. A Treatise of Human Nature. Fontana: Collins.

Husserl, Edmund. 1982. Cartesian Meditations. Trans by Dorion Cairns. The Hague, Boston, London: Martinus Nijhoff.

Jordan, John Welsh. 1997. Value Theory. In The Encyclopedia of Phenomenology, eds. Lester Embree, Elizabeth A. Behnke et al., 724-728. Boston: Kluwer Academic Publishers.

Kant, Immanuel. 2011. Groundwork of the Metaphysics of Morals: A German-English Edition. Trans. and eds. Mary Gregor, Jens Timmerman. Cambridge: Cambridge University Press.

Levinas, Emmanuel. 1963. Théorie de l'intuition dans la phénoménologie de Husserl. Paris: Librairie Philosophique J. Vrin.

Levinas, Emmanuel. 1979. The Contemporary Criticism of the Idea of Value and the Prospects for Humanism. In Value and Values in Evolution, ed. Edward A. Maziarz. 179-192. New York: Gordon and Breach.

Levinas, Emmanuel. 1984. Totalité et infini. The Hague: Martinus Nijhoff.

Levinas, Emmanuel. 1990. Autrement qu'être ou au delà de l'essence. Paris: Le Livre de Poche.

Levinas, Emmanuel. 1992. Totality and Infinity. Trans. Alphonso Lingis. Pittsburgh: Duquesne University Press.

Levinas, Emmanuel. 1995. The Theory of Intuition in Husserl's Phenomenology. Trans. André Orianne. Evanston: Northwestern University Press.

Levinas, Emmanuel. 1997. Otherwise than Being or Beyond Essence. Trans. Alphonso Lingis. London: Kluwer Academic Publishers.

McAleer, Graham. 2006. The Conservative Moral Philosophy of Scheler and Kolnai. Modern Age (Summer): 217-225. 
Nenon, Tom. 1990. Willing and Acting in Husserl's Lectures on Ethics and Value Theory. Man and World 24: 301-309.

Nietzsche, Friedrich. 1989. On the Genealogy of Morals. In On the Genealogy of Morals and Ecce Homo, ed. Walter Kaufmann, 13-163. New York: Vintage Books.

Peucker, Henning. 2007. Husserl's Critique of Kant's Ethics. Journal of the History of Philosophy 45 (2): 309-319.

Pippin, Robert B. 2000. Kant's Theory of Value: On Allen Wood's Kant's Ethical Thought. Inquiry 43 (2): 239-66.

Sartre, Jean Paul. 1947. Une idée fondamentale de la phenomenologie de Husserl: Intentionnalité. In Situations I, 29-32. Paris: Gallimard.

Sartre, Jean-Paul. 1956. Being and Nothingness. Trans. Hazel Barnes. New York: Philosophical Library.

Sartre, Jean-Paul. 1973. Existentialism \& Humanism. Trans. Philip Mairet. London: Methuen.

Sartre, Jean-Paul. 1983. Cahiers pour une morale. Paris: Editions Gallimard.

Sartre, Jean-Paul. 1992. Notebooks for an Ethics. Trans. David Pellauer. Chicago: University of Chicago Press.

Sartre, Jean-Paul. 2000. L'être et le néant. Paris: Gallimard.

Scheler, Max. 1973. Formalism in Ethics and Non-Formal Ethics of Value: A New Attempt Toward the Foundation of an Ethical Personalism. Trans. Manfried S. Frings and Roger L. Funk. Evanston: Northwestern University Press.

Scheler, Max. 2000. Der Formalismus in der Ethik und die materiale Wertethik: Neuer Versuch der Grundlegung eines ethischen Personalismus. Siebte, durchgesehene und verbesserte Auflage, ed. Manfred S. Frings. Bonn: Bouvier. 